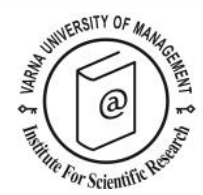

\title{
Drivers of eWOM intensity: differences between hoteliers' perception and real reviews
}

\author{
Javier Perez-Aranda ${ }^{*}$, Manuela Guerreiro ${ }^{2}$ and Júlio da Costa Mendes ${ }^{3}$
}

\footnotetext{
${ }^{1}$ University of Málaga, Faculty of Economics and Business, Department of Business Management, Campus de Teatinos, 29071 Málaga, Spain. E-mail: jpereza@uma.es

${ }^{2}$ Research Centre for Tourism, Sustainability and Well-being (CinTurs) of Universidade do Algarve, Faculty of Economics, Campus de Gambelas, 8005-139 Faro, Portugal. E-mail: mmguerre@ualg.pt

3 Research Centre for Tourism, Sustainability and Well-being (CinTurs) of Universidade do Algarve, Faculty of Economics, Campus de Gambelas, 8005-139 Faro, Portugal. E-mail: jmendes@ualg.pt

* Corresponding author
}

\begin{abstract}
This study aims to determine whether eWOM intensity is related to use intensity, commitment, and competence of brands' review sites. The study is applied to hotels on TripAdvisor and compares brand's perception and real effects. Results of a survey of 332 hotels listed on TripAdvisor are compared with data collected from TripAdvisor. The method consists of comparing these data with the perception of hoteliers, to determine if the drivers use intensity, commitment, and competence have similar effects on eWOM intensity. Regarding correlation analysis, some similarities are found, all drivers included in both models are positively correlated with each explained variable. However, regression analysis revealed differences between drivers of eWOM intensity when the explained variable is based on hoteliers' perception instead of objective data. While, no variable is significant when eWOM intensity is based on perception, the variable use intensity shows a significant relation, when eWOM intensity is assessed by actual reviews. The findings suggest that use intensity is a determinant factor of eWOM intensity. Furthermore, differences between brands' perception and real reviews are observed.
\end{abstract}

Keywords: eWOM intensity, brand engagement, interactional psychology, review sites, perception

Citation: Perez-Aranda, J., Guerreiro, M. and Da Costa Mendes, J. (2021). Drivers of eWOM intensity: differences between hoteliers' perception and real reviews. European Journal of Tourism Research 27, 2708. 


\section{Introduction}

The development of social media and review sites has become increasingly important in travel and tourism (Ilieva and Ivanov, 2014; Nezakati et al., 2015) and has changed the way the hotel industry and tourists communicate and interact with each other. Social media websites have changed tourists' decision-making process (Chen et al., 2015). The consolidation of social media has enabled the development of platforms that strengthen the role of users and customers as producers of electronic word-of-mouth (eWOM) information. Nevertheless, the way organisations manage review sites may be an opportunity to develop a profitable relationship with consumers and to attract new customers (Perez-Aranda et al., 2019).

Much attention has been given to eWOM by both marketing researchers and practitioners, being considered a highly influential source of information (Zainal et al., 2017). Electronic word-of-mouth is widely regarded as "any positive or negative statement made by potential, actual, or former customers about a product or company, which is made available to a multitude of people and institutions via the Internet" (Hennig-Thurau et al., 2004, p. 39). Also, eWOM is highly credible, relevant, and generates empathy with other members $(\mathrm{Xu}, 2014)$. Furthermore, successful online review sites rely on usergenerated content rather than on company-generated content (e.g., TripAdvisor), widely used as a source of data in the field of tourism (Xiang et al., 2017). eWOM intensity is a measure of online wordof-mouth related to activity, volume, and dispersion of eWOM received (Goyette, Ricard, Bergeron and Marticotte, 2010). In previous literature eWOM intensity has been related to engagement (Bonsón et al. 2016; Williams et al. 2010) and brand loyalty (Cheung et al., 2014) directly and indirectly through online community commitment (Zheng et al., 2015).

Literature on eWOM suggests that destination managers need to develop social media strategies (LunaCortés, 2017) to meet the needs of current and future visitors (Williams et al., 2017). Therefore, identifying the determinants of eWOM intensity and differences between hoteliers' perception of eWOM received and real reviews received can help managers in their efforts to improve expected service and social media-based communication on review platforms. Previous studies on eWOM intensity have focused mainly on the effect on consumers (Rossmann et al., 2016) and on guest reviews posted on consumer-generated websites (Mauri and Minazzi, 2013). To date there are no published studies or models investigating commitment, competence, and use intensity as determinants of eWOM intensity. In addition, further studies are required to determine how improve eWOM engagement and to deepen eWOM intensity drivers.

In order to bridge this gap, this study focuses on the relationship between consumer eWOM intensity and brands' review sites use intensity, commitment, and competence. The objective of the study is to determine if those variables are related to eWOM intensity and if there are differences between use intensity, commitment, and competence as predictors of eWOM intensity as perceived by hoteliers and use intensity, commitment, and competence as predictors of eWOM intensity from reviews received. In sum, this study contributes to literature in three ways. First, it applies interactional psychology theory to consumer engagement. Secondly, it studies the effect of hoteliers' review sites use intensity, commitment, and competence on consumer engagement. Third, it compares real data with brands' perception. Results offer insights into eWOM intensity drivers from the number of reviews received which are a main determinant for rankings in algorithms of review platforms.

To compare the results of both contexts (hoteliers' perception and real reviews received) two samples were collected during the same year and from the same hotels listed on TripAdvisor. Then, two models were developed using the same variables (use intensity, competence, and commitment) as predictors 
of eWOM intensity (hoteliers' perception in the first model: Model 1, and from real reviews in the second model: Model 2). For this study, since hoteliers deal directly and frequently with online review management, they are considered as a valuable source of information on eWOM intensity drivers' perception. However, their perception remains poorly studied.

This paper is structured into three main parts: the first part deals with the literature review and hypotheses development aiming to clarify the state of the art and study conceptualization; the second, based on correlation and regression studies, describes the methodology of the empirical study, results obtained and the analysis of data; and, finally, discussion and conclusions, as well as future research suggestions, are presented.

\section{Conceptual framework and hypotheses development eWOM intensity}

The digital revolution has brought major changes to communication, customer behaviour, and brand management (Kaplan and Haenlein, 2010), bringing what is commonly called the democratization of content (Mellinas and Reino, 2019). Things have changed strikingly. Consumers are more likely to use UGC platforms, not only searching for products and services but also to engage with companies they buy from or with other consumers to share experiences or perceptions (Kaplan and Haenlein, 2010; Kaplan and Haenlein, 2011). Consequently, the eWOM message can be disseminated to wider audiences (Jacobsen and Munar, 2012). Furthermore, the growing sophistication of products and services played a significant role in sharing and reading online opinions (Gil-Or, 2010). Therefore, the more consumers believe that generating content will lead to social integration, the more they will generate content (Romero, 2017). In addition, many researchers and different bodies of literature - including psychology (Men and Tsai, 2013), fashion (Wolny and Mueller, 2013), movie industry (Lee et al., 2016), and other fields (Reza and Samiei, 2012) - have sought to understand the relationship between customer engagement in eWOM communities.

Those changes have affected also the tourism industry where eWOM communication has affected the tourism environment by changing the behaviour of both tourists and tourism businesses (Jacobsen and Munar, 2012), dramatically changing its competitive landscape (Buhalis, 2003). First, online travel platforms have become popular among tourists (Xiang and Gretzel, 2010); second, in terms of eWOM intensity, consumers have become more engaged, since online review platforms allow tourists to challenge and collaborate in producing, sharing, and distributing travel information on the Internet (Williams et al., 2010). This engagement is considered similar to the psychological, cognitive, and emotional levels shown by customers while interacting with a certain brand or organisation (Patterson et al., 2006).

The theoretical framework on customer engagement usually follows two approaches: Psychological and behavioural (Romero, 2017). The psychological state comprises cognitive, emotional/affective, and behavioural elements (Brodie et al., 2011; Dessart et al., 2015), under the latter element, customer engagement covers non-transactional customer behaviour (Van Doorn et al., 2010). According to Saks, engagement is argued to be positively related to individuals' attitudes (Saks, 2006). The behavioural approach of customer engagement is involved in emotional aspects (feeling either positive or negative about the company's activities), cognitive aspects (being interested in the company's activities), and behavioural aspects (participation in the company's activities, WOM, co-creation) (Romero, 2017). In this study, even if the behavioural approach is at an early stage in literature (Romero, 2017), as in previous social networks literature (Halaszovich and Nel, 2017; Simon et al., 2016; Tafesse, 2016), the behavioural approach is followed. 
Furthermore, while eWOM comprises qualitative and quantitative approaches to reviews (Jiyao, 2014) - including comments, likes, evaluations - eWOM intensity is a measure of online word-of-mouth related to activity, volume, and dispersion of eWOM received (Goyette, Ricard, Bergeron and Marticotte, 2010). Moreover, in some tourism literature, many engagement-based concepts have been proposed, such as number of user-generated hotel reviews (Park and Allen, 2013; Wei et al., 2013; ShuChuan et al., 2019), which is in line with the approached followed.

According to eWOM intensity literature, on-line platform managers can develop several actions. On the one hand, they can develop programs that appeal to the basic motives that drive eWOM engagement, such as special services (discussion forums, blogs) to increase community coherence and activity and, on the other hand, they can undertake research to better understand consumer use of online platforms (Hennig-Thurau et al., 2004). Bulut and Karabulut (2018) argue that the quantity of eWOM messages have direct effects on on-line repurchase intentions, thus, companies should aim at more intensive eWOM content to increase sales.

The increasing prevalent eWOM research interest makes it relevant to examine eWOM intensity in the tourism industry. eWOM research, as a consumer demand dimension (Buhalis and Law, 20o8), focuses on its impact on customers (Guesalaga, 2016; Mauri and Minazzi, 2013; Romero, 2017), whereas only a few studies focus on its effects on companies (Dijkmans et al., 2015). Indeed, these latter studies, even obtaining positive results, typically do not focus on eWOM intensity from the hoteliers' perspective but on related concepts like brand attitude, or financial results. For example, the influence of web reviews on expectations and on purchasing intentions of hotel potential customers (Mauri and Minazzi, 2013).

\section{Interactional Theory}

Marketing literature shows that relationship marketing theory and service-dominant logic theory are the main theoretical approaches to customer engagement, followed by social exchange theory, uses and gratifications theory, and stimulus-organism-response model, (Islam and Rahman, 2016). Other theories, such as organisational psychology, resource exchange theory, and affordance theory, among others, are less common. This literature review shows that organisation characteristics have been largely ignored in eWOM intensity studies despite its importance on predicting and understanding psychological and behavioural outcomes. This situation highlights a gap in the literature on the use of the interactional psychology approach to eWOM intensity. This study aims to bridge this gap by applying interactional psychology (Lewin, 1940). This theoretical approach relevance is based on the holistic view it offers to eWOM intensity literature.

From an interactional psychology perspective, behaviour is the result of internal (personal) and external (environmental) factors. For Bijou and Baer (1961), an interaction between behaviour and environment means: "That a given response may be expected to occur or not, depending on the stimulation the environment provides". According to this theory, the number of reviews received (eWOM intensity) is not only influenced by tourist internal factors, it also interplays with external factors, suggesting tourist reviews are shaped by an interaction between the characteristics and motivations of tourists for reviewing, and the organisation characteristics. These organisation characteristics (e.g. organisational commitment) influence the outcomes (i.e. number of reviews received).

The interactional theory distinguishes between personal and environmental factors. In this research, to focus on environmental factors - and based on previous work by Guesalaga (2016) - only the factors organisational "competence" and "commitment", together with organisational "use intensity" because of its potential to influence eWOM intensity, were analysed as determinants of behaviour. Therefore, 
other factors such as ease of use, perceived value, or innovation were not included. In this study organisational commitment defined by Guesalaga (2016) is assumed to be predictor of eWOM intensity instead of other commitment approaches such as affective and normative commitment (Cheung and Lee, 2012; Jin et al., 2010), or personal commitment (Glynn et al., 1999). Table 2 shows the variables and sources included in the study and Appendix 1 presents the measures for the variables.

\section{Research hypotheses}

In the development of hypotheses, the organisations' perception of reviews received (importance, effects, frequency) were taken into account. We assumed that the perception of reality does not necessarily correspond with the objective reality (Nisbett and Ross, 1980) and that a normal part of everyday human cognition has a certain degree of illusion (Akerman et al., 2007).

The first pair of hypotheses is related to use intensity. Social media use intensity is described in literature as the level of activity developed in social media (Thoumrungroje, 2014). Academic literature based on the relationship between social network sites (SNS) use intensity and engagement, from the consumers' point of view, is large (Eszter and Yu-li, 2010; Gilbert and Karahalios, 2009; Junco, 2012). Junco (2012) worked with a sample of 2,368 college students to relate frequency of Facebook use, participation in Facebook activities, and student engagement. In his study, Junco measures engagement in three different ways: A 19-item scale, time spent preparing for class, and time spent in co-curricular activities and concludes, based on linear regression analyses, that time spent on Facebook can be positively predictive, negatively predictive, or negatively and positively predictive of student engagement, depending on the way engagement is measured. Furthermore, Thoumrungroje, (2014) investigated the relationship between social media use and consumers' reliance on eWOM. With a sample of 1,142 Thai consumers and using structural equations, the author found that the intensity of social media use has a positive impact on the consumption of conspicuous goods and reliance on eWOM. Indeed, Gilbert and Karahalios (2009) using a dataset of 2,00o social media connections developed a predictive model that maps social media data to tie strength concluding intensity is one of main predictors of tie strength in social media. In addition, Eszter and Yu-li (2010) using a sample of 1,06o young adults and OLS regression concluded that the more intense users of such sites engage in more social activities on social networks than those who spend less time on them. Nevertheless, the study of Eszter and Yu-li (2010), given the cross-sectional nature of data, does not examine the relationship between engagement and SNS use intensity, instead, it focuses on gender differences or level of commitment to explain engagement. Eszter and Yu-li's (2010) research does not allow exploring the causality between SNS engagement and the various activities in which users participate in such sites. The authors concluded SNS usage intensity could provide useful insights for understanding SNS practices better.

From an organisational point of view, Hennig-Thurau et al., (2004) have used multiple regressions to study platform assistance as a predictor of platform visiting frequency with a sample of 2,063 consumers that actively engage in Web-based opinion platforms. In the tourism literature, previous organisational based research showed that eWOM communication (as a way of using eWOM) may increase organisational capability for consumer engagement (Wang 2017). Wang, conducted in-depth interviews with social media workers from three tourism service providers and six affordances of eWOM supporting customer engagement were identified: Interactive affordance, reach affordance, sharing affordance, visibility affordance, monitorability affordance, and co-creation affordance. Therefore, according to previous literature, the first pair of hypotheses is formulated: 
H1a: According to hoteliers' perception of reviews received, review site use intensity is positively related to eWOM intensity.

Hib: According to the real number of reviews received, review site use intensity is positively related to eWOM intensity.

The second concept related to eWOM intensity in this study is commitment. From a consumer point of view, previous studies have revealed a relationship between user reviews and their commitment to the opinion platform (Cheung and Lee, 2012; Glynn et al., 1999; Jin et al., 2010; Hur, et al., 2011). The results of Jin et al. (2010) show affective commitment (emotional) and normative commitment (the moral obligation one must fulfil) as the key determinants of users' continuance intention to contribute eWOM in online opinion platforms. Other studies of commitment and eWOM have found that affective commitment influences eWOM generation (Cheung and Lee, 2012). Furthermore, Hur, Ahn and Kim (2011) identified commitment to the brand as driver of users' participation in community activities. In addition, studies on eWOM concluded that the level of commitment to an organisation is related to positive and negative comments (Glynn et al., 1999).

Organisational commitment, measured with employees' efforts, proud feelings, and staying feelings toward the brand, has been already related to customer linkage behaviours, including willingness to recommend the brand to relatives, friends, and colleagues (Paulin, et al., 2006). In the case of social networks literature, specific network actions such as a simple apology, some kind of compensation, or problem-solving actions have been related to brand image restore (Lee and Song, 2010), and even, brand loyalty (Im et al., 2012). Furthermore, long-term commitment is recommended for hotel managers' reputation management (Jalilvand et al., 2017). Thus, according to previous literature, a second pair of hypotheses between commitment and eWOM intensity is formulated:

H2a: According to hoteliers' perception of reviews received, organisational commitment is positively related to eWOM intensity.

$H_{2} b$ : According to the real number of reviews received, organisational commitment is positively related to eWOM intensity.

To this end, in addition to use intensity and commitment, this study analyses the relationship between competence and eWOM intensity. Consumers' competence is long related in academic literature with different aspects of eWOM, such as behavioural intention to shop on-line (Cheung, et al., 2009); service failure (Funches, et al., 2010); and consumers' positive response and purchase intention (Gao, et al., 2017).

Among studies of organisational competence and their influence on eWOM, Guesalaga's work stands out (Guesalaga, 2016). The author, based on multiple regression analysis from a sample of 220 sales executives in the United States, highlights that an increase in organisational competence has a great impact on social media use. According to Guesalaga (2016), competence is related to the company's knowledge about the UGC platform such as adoption of technology and knowledge, productive use, and active use. In contrast, tourism literature based on the influence of organisational competence on received eWOM is not prolific. Nevertheless, organisational competence on social media has been paid attention in business studies (Jeanquart and Glynn, 2014; Taylor, et al., 2016). Taylor, Haggerty, Gresty and Berry literature review (2016), examines the main types of misuse (discrimination, violations of confidentiality, defamation...) in social media by workforce. In this line, Jeanquart and Glynn study (2014), conclude that employee voice, as an organisational resource, can be a social media time bomb waiting to detonate. Both studies recommend politics and company strategies or guidelines to better 
deal with social media reputation (eWOM). Furthermore, organisational competence has been already related to positive WOM, (Walsh, et al., 2016). Walsh, Schaarschmidt, and von Kortzfleisch study (2016), differ between technical competence, visibility awareness competence, knowledge competence, impact assessment competence and social media communication competence and all types of competence studied results related to positive WOM. Furthermore, Walsh et al., (2016) recommend more research of competence and its effects on reputation. As mentioned, literature on eWOM shows also a relationship between competence and eWOM. Therefore, the following two hypotheses are proposed:

H3a: According to hoteliers' perception of reviews received, organisational competence is positively related to eWOM intensity.

$\mathrm{H}_{3} \mathbf{b}$ : According to the real number of reviews received, organisational competence is positively related to eWOM intensity.

Figure 1 presents the variables included in both models developed.

\section{Model 1: Hoteliers' perception}

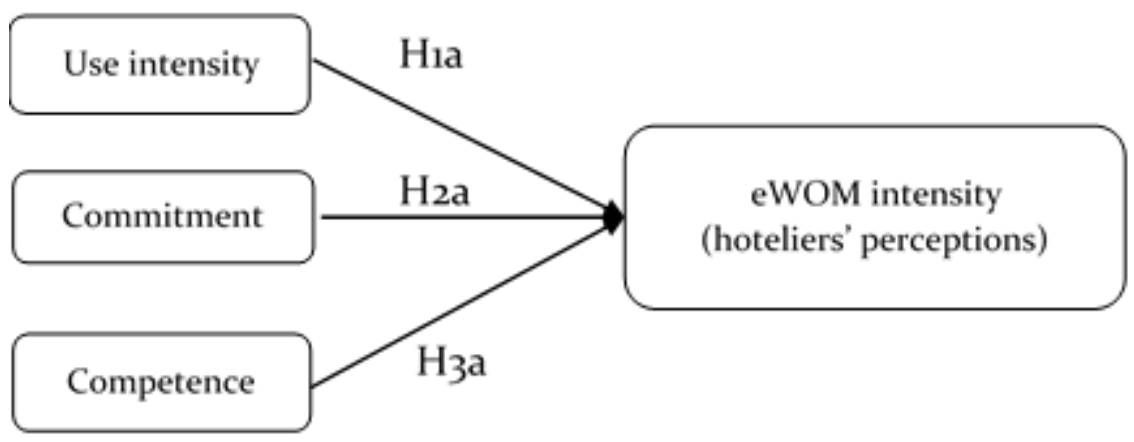

\section{Model 2: Real reviews received}

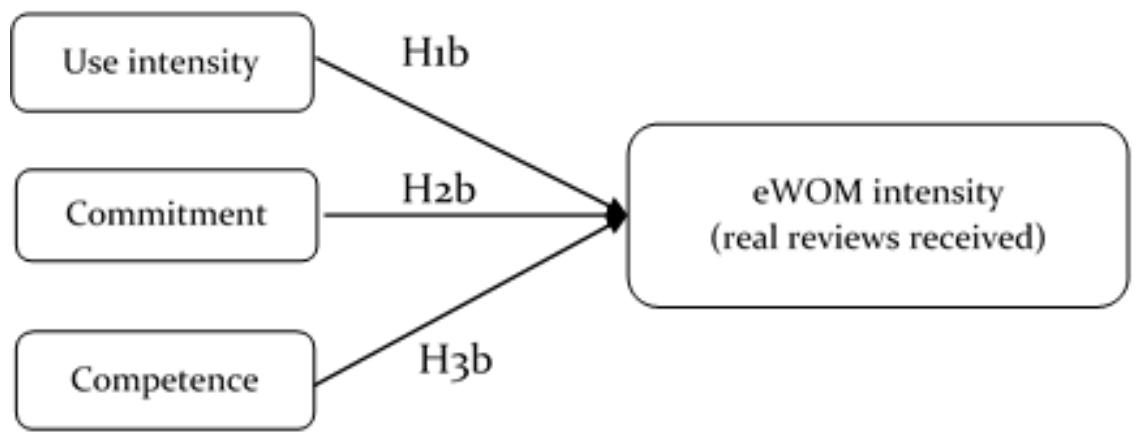

Figure 1. Research models

\section{Method}

Study population and sample

The study population is Spanish accommodation establishments listed on TripAdvisor. In 2016, Spain was again a top tourist destination, the third most visited destination in the world with 75 million 
arrivals (UN World Tourism Organization, 2018). The sample consisted of accommodations establishments on TripAdvisor in the list "selected for you". Through systematic random sampling method, the size of the research sample has been determined to be 335 .

The sampling was developed using two different tools, a questionnaire to assess hoteliers' perceptions and scraping techniques to collect data from TripAdvisor. Double sampling was designed to study and compare results from two different contexts: reality and brands' perception. Finally, following previous literature comparing effects on social media engagement (Junco, 2012) and considering that structural equation models are recommended when testing mediating effects (Ro, 2012), correlation and regression analyses were used to test the hypotheses. Specifically, two different multiple linear regression analysis were applied, one applied to hoteliers' perception of reviews received (dependent variable) and use intensity, commitment, and competence (explaining variables) and, the other, applied to real reviews received on TripAdvisor and the same explaining variables.

\section{Questionnaire design}

The questionnaire was adapted from previous works. The questionnaire structure was as follows. eWOM intensity from hoteliers' perception was measured using construct from the eWOM intensity scale proposition of Goyette, Ricard, Bergeron and Marticotte (2010). The selection of Goyette et al. (2010) construct of eWOM intensity was not random, all variables in this construct are related with frequency and number of reviews received and the measure is easily comparable with real reviews received avoiding additional subjectivity related to the methodology used. The other measured constructs (use intensity, commitment, and competence) were adapted from Guesalaga (2016) research. To end, following Park and Allen (2013), eWOM intensity based in real data was measured with real reviews received. Lastly, hotel characteristics such as hotel category, ownership structure, number of employees, and number of beds were collected.

\section{Data collection}

For data collection purposes, hotels were selected from the review site TripAdvisor, one of the main review sites of the world. Operating worldwide, TripAdvisor is one of the widely used UGC platforms as a way of consulting data (Xiang et al., 2017). According to Xiang et al. (2017), the platform has been extensively used for tourism studies, especially in mixed methods research and content analysis, to examine issues related to hotel, eWOM, readability, reviewer characteristics, ratings, and so on (e.g. Sparks et al., 2016).

Final questionnaire (Table 5) is a result of a designing process based on a pretest presented to a group of fifteen marketers, hotel managers, and academics. The questionnaire was divided in three constructs about drivers with eleven questions in total and four questions related to hotel characteristics. Variables are distributed as following: Use of review sites (1), competence (4), commitment (3), and eWOM intensity (3). For precision measurement purposes, all variables were measured with a 10-item Likert scale ranging from 1 - strongly disagree to 10 - strongly agree (Wittink and Bayer, 2003). In the case of real reviews, the variable studied number of reviews and information is obtained directly from website with a rank from o reviews to 387 reviews. Reviews were gathered in a same period to avoid time biases (Wu et al., 2018).

Since Perfil Plus, the software for accommodations engagement management by TripAdvisor was replaced for Ventaja Plus (TripAdvisor Insights, 2017) in 2017, all data were collected during 2016 to avoid bias. The data collection process was double. Firstly, 332 valid hoteliers' data were obtained following systematic random sampling techniques; first a list of hotels in TripAdvisor (selected for you) 
was downloaded; the first unit of the sample was chosen randomly, following cases were chosen every 6 elements of the list. Once, hotels of sample were selected, telephone interviews were conducted during April and May 2016. Six interviewers were trained to minimise response errors and conduct the survey. Hotel managers and staff related to eWOM management were the key informants selected to answer the survey. To minimise sample bias, meetings were arranged to avoid non-responses because of availability and to ensure anonymity (Podsakoff et al., 2003). Secondly, in 2017, following Rahmani et al. (2014) uses of social media data as a source for mining opinion, real reviews received in TripAdvisor from September to December 2016 by hotels in the sample were collected. Following previous studies on social media brands (Aggrawal et al., 2017), scrapping techniques were used for plain text extraction purposes. Google Web Scraper, version 1.7 was the selected tool.

The sample obtained was the number of reviews received in TripAdvisor in the selected period. Finally, in 16 cases (hotels) scraped data was unviable (no same profiles were available or hotels were not operating during this sampling period), so only 319 cases were considered valid for statistical analysis. Table 2 shows the technical data.

After this process, in order to allow for a more straightforward comparison of perception and reality, since the variable eWOM intensity from hoteliers' perception was formed by three items related to number of reviews received and real reviews variable was formed by an item only, eWOM intensity from hoteliers' perception was re-codified into one-item variable. Therefore, the objective of the study is reinforced and hoteliers' perception regression results can be better related with real reviews regression results. Consequently, results from hoteliers' perception can be compared with more accuracy with real data, already measured with one item. For the rest of variables, to obtain as much information as it could be, no transformations were done.

\section{Data analysis methods}

To assess the overall relationship, the differences between both contexts (hoteliers' perception and real data) and the predictive power of eWOM intensity, multiple linear equations were computed. These models were used because they allow to study the differences on effects of drivers on the dependent variables analysed.

The analysis sequence is as follows. Firstly, an exploratory factor analysis (EFA) was performed for scales (competence, commitment, and eWOM intensity-hoteliers' perception based) using three components with varimax rotation. As shown in Table 1, the indicators for each of the three constructs loaded mainly in one factor (use intensity and eWOM intensity-real data-based variables were not included in the analysis since both were measured by a single item). For all constructs, the EFA suggested a one-factor solution with eigenvalues greater than 1 . The existence of the proposed theoretical concepts and the suitability of the data were checked for all the dimensions in the measurement model. To test validity of the scales Kaiser-Meyer-Olkin was tested. The value of the Kaiser-Meyer-Olkin (KMO) index was 0.884 and Bartlett's test of sphericity was significant (4437.561; $45 \mathrm{df}$ ). The three factors extracted explain $91.36 \%$ of the total variance. Reliability was assessed with Cronbach's alpha, showing values above 0.7 in all items (competence: 0.951; commitment: 0.945, eWOM intensity-hoteliers' perception based: o.941), as required. Since same drivers are used in both regression analyses only one EFA was needed. 
Table 1. Exploratory Factor Analysis

\begin{tabular}{llll}
\hline Item & Component 1 & Component 2 & Component 3 \\
\hline $\begin{array}{l}\text { eWOM intensity x5: eWOM frequency } \\
\text { (same type of company) }\end{array}$ & & 0.921 & \\
eWOM intensity x6: eWOM frequency & & 0.918 & \\
(different type of company) & & \\
eWOM intensity x7: consumers spoke to & & 0.766 & \\
many individuals & & & 0.546 \\
Compet x9: productive use & & 0.593 \\
Compet x10: innovative & & 0.884 \\
Compet x11: knowledgeable & & 0.643 \\
Compet x12: actively use & & \\
Commit x13: social media policy & 0.926 & \\
Commit x14: social media strategy & 0.937 & \\
Commit x15: social media training & 0.778 & \\
\hline
\end{tabular}

Secondly, correlation analysis and multiple linear regression analysis were used to determine the factors that most influence eWOM intensity from the hoteliers' perspective context and from real data context. Correlation analysis was used to identify the relationship between the variables, once the variables were related regression examined the values of influence on related variables. Thus, prior to regression analysis, variables that related significantly were studied using correlation analyses. Normality assessment was studied with the K-S test. The results show significance $0.000(<0.05)$, so variables are not distributed normally. Thus, Kendall's Tau-B and Spearman's Rho coefficients were studied for ordinal variables "use intensity", "competence", and "commitment" and eWOM intensity from both contexts. Stepwise multiple linear regression analysis was selected.

Finally, multiple linear regression tested drivers and dependent variables. The hoteliers' perception model coefficient of determination ( $\mathrm{R}$-squared value) was: 0.539 and $\mathrm{R}^{2}$ adjusted measures: 0.527 ; for the real data model the coefficient of determination was: 0.119 and $\mathrm{R}^{2}$ : 0.096 , showing that the fit was good.

\section{Results}

The descriptive analysis of the sample shows the following figures: $32.3 \%$ of sample are 3-star hotels, 30.3\% are other types accommodations (villas, apartments, rural hotels, 1- and 2-star hotels, etc.), 29.1\% of sample are 4-star hotels, and luxury hotels and 5-star hotels represent $4.2 \%$; regarding to the type of ownership, $71.5 \%$ are independent hotels, $10.4 \%$ form part of an association of independent hotels, $10.7 \%$ form part of a hotel chain, and $\mathbf{1 . 2} \%$ are franchises or other type of chains; taking into account the number of beds, $46.6 \%$ of the sample are family hotels (<10o beds), $22.8 \%$ of the sample are small size hotels (101-150 beds), 21.4\% are medium size hotels (151-30o beds) and 4.7\% large size hotels (>30o beds). The descriptive information is detailed in Table 2, with means, standard deviations, and Pearson correlations. 
Table 2. Means, standard deviations, rank and Pearson correlations

\begin{tabular}{|c|c|c|c|c|c|c|c|c|c|c|c|c|c|}
\hline Variable & Mean & $\begin{array}{l}\text { St. } \\
\text { Dev }\end{array}$ & $\begin{array}{l}\operatorname{Min} / \\
\operatorname{Max}\end{array}$ & $\begin{array}{l}\text { eWOM } \\
\text { int } \\
\left(x_{5}, x_{6}\right. \\
\left.\text { and } x_{7}\right)\end{array}$ & $\begin{array}{l}\text { eWOM } \\
\text { int } \\
\text { (x16) }\end{array}$ & $\begin{array}{l}\text { Use } \\
\text { int } \\
(\mathrm{x} 8)\end{array}$ & $\begin{array}{l}\text { Comp } \\
(\mathrm{x} 9)\end{array}$ & $\begin{array}{l}\text { Comp } \\
(\mathrm{x} 10)\end{array}$ & $\begin{array}{l}\text { Comp } \\
\text { (x11) }\end{array}$ & $\begin{array}{l}\text { Comp } \\
(\mathrm{x} 12)\end{array}$ & $\begin{array}{l}\text { Comm } \\
(\mathrm{x} 13)\end{array}$ & $\begin{array}{l}\text { Comm } \\
(\mathrm{x} 14)\end{array}$ & $\begin{array}{l}\text { Comm } \\
(\mathrm{x} 15)\end{array}$ \\
\hline \multicolumn{14}{|l|}{ Hoteliers' } \\
\hline $\begin{array}{l}\text { eWOM intensity } \\
\text { (mean of x5, x6 } \\
\text { and } x_{7} \text { ) }\end{array}$ & 17.71 & 7.02 & (2) & & & - & & & & & & & \\
\hline Real data & & & & & & & & & & & & & \\
\hline $\begin{array}{l}\text { eWOM intensity } \\
\text { (x16) }\end{array}$ & 19.54 & 35.75 & $0-387$ & 0.221 & - & - & - & - & - & - & - & - & - \\
\hline Use intensity $(\mathrm{x} 8)$ & 7,02 & 2,253 & $1-10$ & 0.596 & 0.324 & - & - & - & - & - & - & - & - \\
\hline Competence (x9) & 7,11 & 2,260 & $1-10$ & 0.596 & 0.310 & 0.932 & - & - & - & - & - & - & - \\
\hline Competence (x10) & 7,04 & 2,161 & $1-10$ & 0.667 & 0.280 & 0.855 & 0.871 & - & - & - & - & - & - \\
\hline Competence (x11) & 7,62 & 2,117 & $1-10$ & 0.596 & 0.170 & 0.669 & 0.693 & 0.757 & - & - & - & - & - \\
\hline Competence (x12) & 7,04 & 2,231 & $1-10$ & 0.569 & 0.258 & 0.848 & 0.907 & 0.837 & 0.781 & - & - & - & - \\
\hline $\begin{array}{l}\text { Commitment } \\
(\mathrm{x} 13)\end{array}$ & 6,59 & 2,419 & $1-10$ & 0.473 & 0.250 & 0.805 & 0.823 & 0.757 & 0.788 & 0.788 & - & - & - \\
\hline $\begin{array}{l}\text { Commitment } \\
\text { (x14) }\end{array}$ & 6,36 & 2,540 & $1-10$ & 0.446 & 0.245 & 0.740 & 0.760 & 0.715 & 0.726 & 0.925 & 0.925 & - & - \\
\hline $\begin{array}{l}\text { Commitment } \\
(\mathrm{x} 15)\end{array}$ & 6,49 & 2,168 & $1-10$ & 0.645 & 0.244 & 0.808 & 0.822 & 0.808 & 0.807 & 0.844 & 0.844 & 0.831 & - \\
\hline
\end{tabular}

Note: All values are significant at $\mathrm{p}<0.01$

Statistical analyses were carried out using SPSS 21.0 program for Windows. In both contexts, the result of the correlation analysis shows significance between competence, commitment, use intensity, and eWOM intensity (perceived by the hoteliers and real data). With these results, all the variables studied are included in the subsequent regressions. Table 3 shows, the values of Kendall's Tau-B, the values of Spearman's Rho and the level of significance.

The purpose of this study was multifaceted. Based on interactional theory, the study focused on the drivers that explain eWOM intensity from two perspectives, the hoteliers' perception and reality. Furthermore, the type of influence of drivers on dependent variables and the differences or similarities shown by drivers in both contexts were thoroughly analysed. Particularly, multiple linear regression analyses were developed to obtain the results. For these analyses, the independent variables, or predictors (use intensity, commitment, and competence) are the correlated variables and eWOM intensity in both contexts is the dependent, or criterion, variable. Tests for multicollinearity and normality of residuals were performed. The multiple regressions used the following models:

Model 1: Hoteliers' perception

eWOM intensity $(H P)=\beta_{0}+\beta_{1}$ Use $_{8}+\beta_{2}$ Compet $_{9}+\beta_{3}$ Compet $_{10}+\beta_{4}$ Compet $_{11}+\beta_{5}$ Compet $_{12}+\beta_{6}$ Commit $_{13}+$ $\beta_{7}$ Commit $_{14}+\beta_{8}$ Commit $_{15}+\varepsilon$

Model 2: Real data

eWOM intensity $(R D)=\beta_{\mathrm{o}}+\beta_{1}$ Use $_{8}+\beta_{2}$ Compet $_{9}+\beta_{3}$ Compet $_{10}+\beta_{4}$ Compet $_{11}+\beta_{5}$ Compet $_{12}+\beta_{6}$ Commit $_{13}+$ $\beta_{7}$ Commit $_{14}+\beta_{8}$ Commit $_{15}+\varepsilon$

The results of regressions are reported in Table 4 with their standard errors and statistical significances. These results empirically confirm that the variables, perceived by hoteliers, explaining eWOM intensity perceived are: competence10, competence11 and competence12, and commitment15 ( $<<0.05)$. Furthermore, results empirically confirm that, measured with real data, use intensity is the solely variable that explain eWOM intensity $(\mathrm{p}<0.05)$. Furthermore, in Model 1 , the effect obtained for 
competence12 is negative while the rest effects obtained in variables with significance are positive. In contrast, in Model 2, only a positive effect is obtained. Finally, the greatest influence on Model 1, from hoteliers' perception, is commit15 $(\beta=0.572)$, followed by compet1o $(\beta=0.379)$. For Model 2 , use intensity influence is $(\beta=0.331)$.

Table 3. Correlation Analyses

\begin{tabular}{|c|c|c|c|c|}
\hline $\begin{array}{l}\text { Model 1: eWOM intensity from } \\
\text { hotelier's perception }\end{array}$ & $\begin{array}{c}\text { Kendall's } \\
\text { Tau-b } \\
\text { coefficient }\end{array}$ & Sig. & $\begin{array}{c}\text { Spearman's } \\
\text { Rho } \\
\text { coefficient }\end{array}$ & Sig. \\
\hline $\begin{array}{l}\text { Use intensity x8 - eWOM intensity } \\
\text { (hoteliers' perception) }\end{array}$ & 0.477 & 0.000 & 0.617 & 0.000 \\
\hline $\begin{array}{l}\text { Competence x9 - eWOM intensity } \\
\text { (hoteliers' perception) }\end{array}$ & 0.479 & 0.000 & 0.620 & 0.000 \\
\hline $\begin{array}{l}\text { Competence x10 - eWOM intensity } \\
\text { (hoteliers' perception) }\end{array}$ & 0.525 & 0.000 & 0.672 & 0.000 \\
\hline $\begin{array}{l}\text { Competence x11 - eWOM intensity } \\
\text { (hoteliers' perception) }\end{array}$ & 0.429 & 0.000 & $0.55^{8}$ & 0.000 \\
\hline $\begin{array}{l}\text { Competence x12 - eWOM intensity } \\
\text { (hoteliers' perception) }\end{array}$ & 0.457 & 0.000 & 0.590 & 0.000 \\
\hline $\begin{array}{l}\text { Commitment x13 - eWOM intensity } \\
\text { (hoteliers' perception) }\end{array}$ & 0.403 & 0.000 & 0.536 & 0.000 \\
\hline $\begin{array}{l}\text { Commitment x14 - eWOM intensity } \\
\text { (hoteliers' perception) }\end{array}$ & 0.387 & 0.000 & 0.510 & 0.000 \\
\hline $\begin{array}{l}\text { Commitment x15 - eWOM intensity } \\
\text { (hoteliers' perception) }\end{array}$ & 0.508 & 0.000 & 0.645 & 0.000 \\
\hline $\begin{array}{l}\text { Model 2: eWOM intensity from } \\
\text { real data }\end{array}$ & $\begin{array}{c}\text { Kendall's } \\
\text { Tau-b } \\
\text { coefficient }\end{array}$ & Sig. & $\begin{array}{c}\text { Spearman's } \\
\text { Rho } \\
\text { coefficient }\end{array}$ & Sig. \\
\hline $\begin{array}{l}\text { Use intensity x8 - eWOM intensity } \\
\text { (real data) }\end{array}$ & 0.368 & 0.000 & 0.487 & 0.000 \\
\hline $\begin{array}{l}\text { Competence x9 - eWOM intensity } \\
\text { (real data) }\end{array}$ & 0.341 & 0.000 & $0.45^{2}$ & 0.000 \\
\hline $\begin{array}{l}\text { Competence x10 - eWOM intensity } \\
\text { (real data) }\end{array}$ & 0.320 & 0.000 & 0.426 & 0.000 \\
\hline $\begin{array}{l}\text { Competence x11 - eWOM intensity } \\
\text { (real data) }\end{array}$ & 0.211 & 0.000 & 0.284 & 0.000 \\
\hline $\begin{array}{l}\text { Competence x12 - eWOM intensity } \\
\text { (real data) }\end{array}$ & 0.326 & 0.000 & 0.436 & 0.000 \\
\hline $\begin{array}{l}\text { Commitment x13 - eWOM intensity } \\
\text { (real data) }\end{array}$ & 0.292 & 0.000 & 0.387 & 0.000 \\
\hline $\begin{array}{l}\text { Commitment x14 - eWOM intensity } \\
\text { (real data) }\end{array}$ & 0.282 & 0.000 & 0.376 & 0.000 \\
\hline $\begin{array}{l}\text { Commitment x15 - eWOM intensity } \\
\text { (real data) }\end{array}$ & 0.296 & 0.000 & 0.396 & 0.000 \\
\hline
\end{tabular}


Table 4. Regression Analyses

\begin{tabular}{|c|c|c|c|c|c|c|}
\hline $\begin{array}{c}\text { Model } 1 \\
\text { Predictor }\end{array}$ & B & $\begin{array}{l}\text { Std. } \\
\text { Error }\end{array}$ & Exp. (B) & P-value & Tolerance & VIF \\
\hline Constant & 0.351 & 1.040 & & & & \\
\hline Use8 & 0.221 & 0.347 & 0.524 & 0.071 & 0.115 & 8.664 \\
\hline Compet x9: productive use & 0.276 & 0.432 & 0.522 & 0.089 & 0.074 & 13.448 \\
\hline Compet x10: innovative & 1.232 & 0.299 & 0.000 & 0.379 & 0.169 & $5 \cdot 918$ \\
\hline Compet x11: knowledgeable & 0.604 & 0.239 & 0.012 & 0.182 & 0.274 & 3.649 \\
\hline Compet x12: actively use & -0.693 & 0.348 & 0.047 & -0.220 & 0.117 & $8.55^{2}$ \\
\hline Commit x13: social media policy & -0.593 & 0.345 & 0.086 & -0.204 & 0.102 & 9.830 \\
\hline $\begin{array}{l}\text { Commit x14: social media } \\
\text { strategy }\end{array}$ & -0.418 & 0.294 & 0.155 & -0.151 & 0.127 & 7.845 \\
\hline $\begin{array}{l}\text { Commit15: social media } \\
\text { training }\end{array}$ & 1.855 & 0.283 & 0.000 & 0.572 & 0.188 & $5 \cdot 313$ \\
\hline $\begin{array}{c}\text { Model } 2 \\
\text { Predictor }\end{array}$ & B & $\begin{array}{l}\text { Std. } \\
\text { Error }\end{array}$ & Exp. (B) & P-value & Tolerance & VIF \\
\hline Constant & -11.508 & $7 \cdot 327$ & & & & \\
\hline Use8 & 5.155 & 2.439 & 0.035 & 0.331 & 0.116 & 8.630 \\
\hline Compet x9: productive use & 2.553 & 3.038 & 0.431 & 0.164 & 0.074 & 13.440 \\
\hline Compet x10: innovative & 1.235 & 2.154 & 0.567 & 0.076 & 0.163 & 6.143 \\
\hline Compet x11: knowledgeable & -1.726 & 1.677 & 0.304 & -0.104 & 0.277 & 3.604 \\
\hline Compet x12: actively use & -1.204 & 2.426 & 0.620 & -0.077 & 0.119 & 8.391 \\
\hline Commit x13: social media policy & -2.340 & 2.445 & 0.339 & -0.161 & 0.100 & 9.968 \\
\hline $\begin{array}{l}\text { Commit x14: social media } \\
\text { strategy }\end{array}$ & 1.547 & 2.077 & 0.457 & 0.111 & 0.137 & 7.876 \\
\hline $\begin{array}{l}\text { Commit x15: social media } \\
\text { training }\end{array}$ & -0.789 & 1.985 & 0.691 & -0.049 & 0.189 & 5.295 \\
\hline
\end{tabular}

VIF and tolerance were calculated to assess multicollinearity, all tolerance values were over o.1 or close to 0.1 and all variance inverse factors were under 10 except Compet x9: "productive use", showing acceptable levels of multicollinearity in both models. Overall, the models' coefficient of determination are $\mathrm{R}^{2}=53.9 \%$ (adjusted $\mathrm{R}^{2}=52.7 \%$ ) for Model 1 and $\mathrm{R}^{2}=11.9 \%$ (adjusted $\mathrm{R}^{2}=9.6 \%$ ) for real data. The ANOVA test results show significant interaction effects of the independent variables in both cases (Fvalue: 47.032, p<0.00o) for Model 1 and (F-value: 5.223, p<0.00o) for Model 2. In concordance, it is assumed commitment, competence, and use intensity have a real effect on the hoteliers' perception of eWOM intensity and on eWOM intensity measured with real data. Despite this, regressions only confirmed 4 items of total variables analysed as predictors of Model 1 and 1 variable analysed as predictor of Model 2. According to these results, it is verified the null hypothesis that the model fits the data well.

In summary, for Model 1, since all items in competence and commitment variables were not positive related with eWOM intensity and use intensity neither was, no hypotheses were supported with significance. Furthermore, a negative effect not expected was found for Compet $12(\beta=-0.220 ; p=0.047)$. In contrast, the results of Model 2 support one of the three hypotheses put forward. Hib: "Review site use intensity organisational perception is positively related to eWOM intensity, according to real number of reviews received." was supported $(\beta=0.331 ; p=0.000)$. The differences in results obtained could be explained because of cognitive distortion or context-driven distortion. 


\section{Discussion, conclusions, and limitations}

This study develops two models to identify the drivers of eWOM intensity based on perception of managers in the hotel sector and from real reviews received. Working with a sample of 332 Spanish accommodations listed on TripAdvisor and using regression analyses, the relationships between dependent variables "eWOM intensity-hoteliers' perception" and "eWOM intensity-real data" and independent variables "use intensity", "competence" and "commitment" were analysed. The results indicate there are no predictors of eWOM intensity in Model 1 and use intensity variable $(\beta=0.331)$ is the solely predictor of eWOM intensity in Model 2. To summarise, in both models — hoteliers' perspective and real data - results are different.

After verifying that there is no consensus in academia about customer engagement, this research draws on Park and Allen approach to consumer engagement. Thus, multiple linear regression analyses were performed to study similarities and differences in eWOM intensity measured with hoteliers' perception of reviews received and real reviews received.

This study offers several theoretical contributions. First, the research offers an application of interactional theory to consumer engagement literature. Thus, the research offers an expansion of interactional theory applications since it was not previously applied to eWOM intensity studies. Second, this study empirically relates interactional theory social media organisational factors (commitment and competence) to eWOM intensity hoteliers' perception based and eWOM intensity real reviews based for first time. Third, according to interactional theory organisational factors applied in social media, this research introduces organisational use intensity as a new construct or explaining factor related to eWOM intensity.

Social media brands and organisations aiming to develop strategies to enhance engagement in review sites such as TripAdvisor should consider that results between organisations' point of view and real data are different. The results of this study do not confirm that - from the hoteliers' perspective commitment, competence or use intensity are positively predictors of eWOM intensity; in contrast, results from real reviews suggest that perceived use intensity is the key factor. These findings contribute to make managers aware that, in relation to eWOM intensity drivers; there are differences on eWOM intensity drivers based on perception and eWOM intensity drivers based on real reviews. In addition, only an indirect effect of perceived commitment and competence with real eWOM intensity through perceived use intensity can be assumed. Thus, hotel brands in need of directions and guidelines for managing eWOM should work with those elements to develop managerial strategies for increasing the reviews received.

Another implication of this study is that it is imperative to draw all the consequences of this process in terms of service quality. Although, the content of the review is the element to study for expected service confirmation, the results of this research confirm differences between perception and reality of determinants in reviews received. Those differences may result in a gap between customers expected service and reality. Thus, managers should confirm their perceptions of eWOM by following strategies in line with real data. It is necessary to ensure that companies set guidelines to get and collet information about expected service.

From all studied variables and hypotheses (Appendix 2), only Hib has been supported. Furthermore, results show different values and trends: considering only significant results, predictors of eWOM intensity in Model 1 are: Compet1o (o.379), Compet11 (o.182), Compet12 (-0.220) and Commit15 (0.572); for Model 2: Use8 (o.331). These values indicate, for organisational perception, when an organisation 
adopts productivity-enhancing technology or leaderships are knowledgeable about social media, eWOM intensity received, according to perception, growth (0.379) and (o.182), respectively. Also, if the leadership works with social media, eWOM intensity decreases (0.220). These results are consistent with results from Junco (2012), who found that a variable x could be positively and negatively predictive of engagement, depending on the outcome of the variable. One reason explaining why organisations compet12 is negatively related with eWOM intensity could be that leaderships using social media are more dedicate to communicate and create brand image instead of developing strategies to increase number of reviews received and, in consequence, the engagement measured. Differences between strategies developed and respondents' uses can also explain it. Furthermore, each organisation analysed can work in different strategies while data are collected, from reducing negative reviews to increasing just the number of reviews or implementing strategies to obtain positive reviews.

According to Model 1, organisations and brands interested in improving eWOM intensity should first adopt productivity-enhancing technology and then make leaderships knowledgeable about social media instead of leadership working with social media. Finally, regarding to real reviews received (Model 2), in line with the study of Atmosphere Research Group from TripAdvisor Insights (2015), to improve eWOM intensity, organisations and brands should work with review site use intensity (o.331). The results of this study show that review site use intensity increases 1 unit, eWOM intensity (number or reviews received) improves 0.331 units, that causality applied as a hotel brand eWOM managerial strategy, could be valued by review sites algorithms. Thus, managing frequently the own review site profile, working with reminders for guests and answering to reviews received are examples on how an hotel brand can obtain a higher number of reviews.

\section{Limitations}

There are several limitations in this study. First, the study only considers accommodation establishments listed on a specific eWOM platform (TripAdvisor). Although useful in providing a general picture, the findings of this study cannot be generalized to all types of accommodations or review sites. In addition, since the objective of the study was to measure the effects of use intensity, commitment, and competence on eWOM intensity from two different contexts, personal characteristics (age, gender), and organisational characteristics (hotel size, type of management) were not included. Another limitation of the study is that eWOM intensity from hoteliers' perception is analysed with a three-item variable, advanced customer engagement constructs are not included in the study. Furthermore, item Compet x9: "productive use" has a high level of multicollinearity. Future studies should contrast these results with other customer engagement constructs. In addition, real reviews studied present some limitations to achieve reliable results since are gathered for a specific period instead of all the sequence. Furthermore, cross-cultural differences are not analysed in the study. Therefore, future studies should compare the effects of cross-country perceptions and take into account full sequences of reviews received. Also, future studies could segment the experiment according to the characteristics of accommodation establishments, such as size, category, or type of management. In addition, further studies could analyse managers' perceptions of organisations listed on different review sites or eWOM platforms and consider all type of reviews: Positive, very positive, negative, very negative. Finally, it is important also to investigate indirect effects between eWOM intensity and competence or commitment through use intensity.

Funding: This work was supported by Plan Andaluz de Investigacion Desarrollo e Innovacion (Convocatoria 2017) Grupo SEJ-567 (Spain); and Portuguese National Funds provided by FCTFoundation for Science and Technology, through project UIDB/o4020/2020. 


\section{References}

Aggrawal, N., Ahluwalia A., Khurana P. \& Arora, A. (2017). Brand analysis framework for online marketing: ranking web pages and analyzing popularity of brands on social media. Social Network Analysis and Mining, 7(1), 21.

Akerman, A., Williams, M.E. \& Meunier, J. (2007). Perception versus reality: an exploration of children's measured body mass in relation to caregivers' estimates. Journal of Health Psychology, 12(6), 871882.

Bijou S.W. \& Baer, D.M. (1961). Child development. Vol 1. A systematic and empirical theory.

Bonsón, E., Bednárová, M. \& Wei, S. (2016). Corporate Twitter use and stakeholder engagement: An empirical analysis of the Spanish hotel industry. European Journal of Tourism Research, 13, 69.

Brodie R.J., Hollebeek, L.D., Juric' B. \& LLic' A. (2011). Customer engagement: Conceptual domain, fundamental propositions, and implications for research. Journal of Service Research, 14(3), 252-271. https://doi: 10.1177/1094670511411703

Buhalis, D. (2003). eTourism: Information technology for strategic tourism management. Pearson education.

Buhalis, D. \& Law, R. (2008). 22Progress in information technology and tourism management: 20 years on and 10 years after the Internet-The state of eTourism research. Tourism Management, 29(4), pp. 609-623.

Bulut, Z.A. \& Karabulut, A.N. (2018). Examining the role of two aspects of eWOM in online repurchase intention: An integrated trust-loyalty perspective. Journal of Consumer Behaviour, 17(4), 407-417.

Chen, C-H., Nguyen, B., Klaus, P. \& Wu, M-S. (2015). Exploring Electronic Word-of-Mouth (eWOM) in The Consumer Purchase Decision-Making Process: The Case of Online Holidays - Evidence from United Kingdom (UK) Consumers. Journal of Travel and Tourism Marketing, 32(8), 953-970

Cheung, C.M. \& Lee, M.K. (2012). What drives consumers to spread electronic word of mouth in online consumer-opinion platforms. Decision Support Systems, 53(1), 218-225. https://doi: 10.1016/j.dss.2012.01.015

Cheung, C.M., Lee, M. K. \& Thadani, D. R. (2009, September). The impact of positive electronic wordof-mouth on consumer online purchasing decision. In World Summit on Knowledge Society, Springer, Berlin, Heidelberg, 501-510.

Cheung, C.M., Zheng, X. \& Lee M.K. (2014). Customer loyalty to $\mathrm{C}_{2} \mathrm{C}$ online shopping platforms: An exploration of the role of customer engagement. System Sciences (HICSS) 2014, 47th Hawaii International Conference, 3065-3072. https://doi: 10.1109/HICSS.2014.382

Dessart, L., Veloutsou, C. \& Morgan-Thomas, A. (2015). Consumer engagement in online brand communities: a social media perspective. Journal of Product \& Brand Management, 24 (1), $28-42$.

Dijkmans, C., Kerkhof, P. \& Beaukeboom, C.J. (2015). A stage to engage: Social media use and corporate reputation. Tourism Management, 47, 58-67.

Gao, L., Li, W.L. \& Ke, Y.L. (2017). The impact of eWOM on consumers' purchasing intention in social commerce: The mediating effect of affective response and the moderating effect of curiosity. Journal of Industrial Engineering and Engineering Management, 4, 3.

Gilbert, E. \& Karahalios. K. (2009). Predicting tie strength with social media. In Proceedings of the SIGCHI Conference on Human Factors in Computing Ssystem, 211-220. doi: 10.1145/1518701.1518736

Gil-Or, O. (2010). Building consumer demand by using viral marketing tactics within an online social network. Advances in Management, 3 (7), 7-14.

Glynn, W., Miller, F. \& Brockway, G.R. (1999). Word-of-mouth communication in the service marketplace. Journal of Services Marketing, 13 (1), 73-89.

Goyette, I., Ricard, L., Bergeron, J. \& Marticotte, F. (2010). e-WOM Scale: word-of-mouth measurement scale for e-services context. Canadian Journal of Administrative Sciences/Revue Canadienne des Sciences de l'Administration, 27(1), 5-23. 
Guesalaga, R. (2016). The use of social media in sales: Individual and organizational antecedents, and the role of customer engagement in social media. Industrial Marketing Management, 54, 71-79. doi: 10.1016/j.indmarman.2015.12.002

Funches, V.M., Foxx, W., Park, E. J. \& Kim, E. Y. (2010). Assessing the damage: An exploratory examination of electronic word of mouth. Journal of Global Academy of Marketing Science, 20 (2), 188-198.

Halaszovich, T. \& Nel, J. (2017). Customer-Brand engagement and Facebook fan-page "Like"intention. Journal of Product \& Brand Management, 26 (2), 120-134.

Islam, J.U. \& Rahman, Z. (2016). The transpiring journey of customer engagement research in marketing: A systematic review of the past decade. Management Decision, 54 (8), 2008-2034.

Hennig-Thurau T., Gwinner K.P., Walsh, G. \& Gremler, D.D. (2004). Electronic word-of-mouth via consumer-opinion platforms: what motivates consumers to articulate themselves on the internet? Journal of Interactive Marketing, 18(1), 38-52.

Hornik J., Satchi, R.S., Cesareo, L. \& Pastore A. (2015). Information dissemination via electronic wordof-mouth: Good news travels fast, bad news travels faster! Computers in Human Behavior, 45, 27328o. https://doi: 10.1016/j.chb.2014.11.008

Hur, W.M., Ahn, K.H. \& Kim, M. (2011). Building brand loyalty through managing brand community commitment", Management Decision, 49(7), 1194-1213.

Ilieva, D., \& Ivanov, S. H. (2014). Analysis of online hotel ratings: the case of Bansko, Bulgaria. Bulgaria (September 15, 2014).

Im, H.H., Kim, S.S., Elliot, S. \& Han, H. (2012). Conceptualizing Destination Brand Equity Dimensions from a Consumer-Based Brand Equity Perspective. Journal of Travel and Tourism Marketing, 29(4), 385-403. doi: 10.1080/10548408.2012.674884

Jacobsen, J.K.S. \& Munar, A.M. (2012). Tourist information search and destination choice in a digital age. Tourism Management Perspectives, 1, 39-47.

Jalilvand, M.R., Nasrolahi, L., Kazemi, H. \& Khazaei, J. (2017). Social responsibility influence on customer trust in hotels: mediating effects of reputation and word-of-mouth. Tourism Review, 72 (1), 1-14.

Jeankart, S. \& Glynn, W. (2014). Employee voice: Untapped resource or social media time bomb? Business Horizons, 57(3), 401-411.

Jin, X., Xiang, L., Lee, M.K., Cheung, C.M., Zhou, Z. \& Zhao, D.T. (2010). Electronic Word-Of-Mouth Contribution Continuance in Online Opinion Platforms: The Role of Multiple Commitments", PACIS, 149.

Jiyao, X. (2014). Revisiting the two-stage choice model: an empirical study of consumer choice on brand website visits. Behaviour \& Information Technology, 33(11), 1192-1207.

Junco, R. (2012). The relationship between frequency of Facebook use, participation in Facebook activities, and student engagement. Computers $\mathcal{E}$ Education, 58(1), 162-171. https://doi: o.1016/j.compedu.2011.08.004

Kaplan, A.M. \& Haenlein, M. (2010). Users of the world, unite! The challenges and opportunities of Social Media. Business Horizons, 53(1), 59-68. https://doi: 10.1016/j.bushor.2009.09.003

Kaplan, A.M., Haenlein, M. (2011). Two hearts in three-quarter time: How to waltz the social media/viral marketing dance", Business Horizons, 54(3), 253-263.

Kaya, M. \& Alhajj, R. (Eds.) (2019). Influence and Behavior Analysis in Social Networks and Social Media, Springer International Publishing.

Lee, H., Lee, H.J., Cruz, R.A. \& Enriquez, J.L. (2016). Electronic word of mouth (eWOM) in the movie industry. Proceedings of the 18th Annual International Conference on Electronic Commerce: eCommerce in Smart connected World, ACM. https://doi: 10.1145/2971603.2971610 
Lee, Y.L. \& Song, S. (2010). An empirical investigation of electronic word-of-mouth: Informational motive and corporate response strategy. Computers in Human Behavior, 26(5), 1073-1080. https://doi: 10.1016/j.chb.2010.03.009

Lewin, K. (1940). Part One: Formalization and Progress in Psychology.

Luna-Cortés, G. (2017). The influence of tourism experience self-congruity on the use of virtual social networks. European Journal of Tourism Research, 16, 154-176.

Mauri, A.G. \& Minazzi, R. (2013). Web reviews influence on expectations and purchasing intentions of hotel potential customers. International Journal of Hospitality Management, 34, 99-107. https://doi: 10.1016/j.ijhm.2013.02.012

Mellinas, J.P. \& Reino, S. (2019). eWOM: the importance of reviews and ratings in tourism marketing. In Strategic Perspectives in Destination Marketing, IGI Global, 143-173.

Men, L.R. \& Tsai, W.H.S. (2013). Beyond liking or following: Understanding public engagement on social networking sites in China. Public Relations Review, 39(1), 13-22. https://doi:10.1016/j.pubrev.2012.09.013

Nezakati, H., Amidi, A., Jusoh, Y. Y., Moghadas, S., Aziz, Y. A. \& Sohrabinezhadtalemi, R. (2015). Review of social media potential on knowledge sharing and collaboration in tourism industry. Procediasocial and behavioral sciences, 172, 120-125.

Nisbett, R.E. \& Ross, L. (1980). Human inference: Strategies and shortcomings of social judgment.

Park, S-Y. \& Allen, J.P. (2013). Responding to online reviews: Problem solving and engagement in hotels. Cornell Hospitality Quarterly, 54(1), 64-73. https://doi: 10.1177/1938965512463118

Patterson, P., Yu, T. \& De Ruyter, K. (2006). Understanding customer engagement in services. Advancing theory, maintaining relevance, proceedings of ANZMAC 2006 conference, Brisbane.

Paulin, M., Ferguson, R. J. \& Bergeron, J. (2006). Service climate and organizational commitment: The importance of customer linkages. Journal of Business Research, 59 (8), 906-915.

Perez-Aranda J., Anaya-Sanchez R. \& Ruizalba, J. (2017). Predictors of review sites usage in hotels. Tourism \& Management Studies, 13(2), 52-59.

Perez-Aranda, J., Vallespín, M. \& Molinillo, S. (2019). Hotels' online reputation management: benefits perceived by managers. International Journal of Contemporary Hospitality Management, 31(2), 615632.

Phang, C.W., Zhang, C. \& Sutanto, J. (2013). The influence of user interaction and participation in social media on the consumption intention of niche products. Information $\mathcal{E}$ Management, 50(8), 661672. https://doi: 10.1016/j.im.2013.07.001

Podsakoff, P.M., MacKenzie, S.B., Lee, J.Y. \& Podsakoff, N.P. (2003). Common method biases in behavioral research: a critical review of the literature and recommended remedies. Journal of Applied Psychology, 88(5), 879. https://doi: 10.1037/o021-9010.88.5.879

Rahmani, A., Chen, A., Sarhan, A., Jida, J., Rifaie, M. \& Alhajj, R. (2014). Social media analysis and summarization for opinion mining: a business case study. Social Network Analysis and Mining, 4(1), 171.

Reza, M. \& Samiei, N. (2012). The impact of electronic word of mouth on a tourism destination choice: Testing the theory of planned behavior (TPB). Internet Research, 22 (5), 591-612.

Ro, H. (2012). Moderator and mediator effects in hospitality research. International Journal of Hospitality Management, 31(3), 952-961.

Romero, J. (2017). Exploring customer engagement in tourism: Construct proposal and antecedents. Journal of Vacation Marketing, 24(4), 292-306.

Rossmann, A., Rossmann, A., Ranjan, K.R., Ranjan, K.R., Sugathan, P. \& Sugathan, P. (2016). Drivers of user engagement in eWOM communication. Journal of Services Marketing, 30 (5), 541-553.

Saks, A.M. (2006). Antecedents and consequences of employee engagement. Journal of Managerial Psychology, 21 (7), 60o-619. 
Simon, C., Brexendorf, T.O. \& Fassnacht, M. (2016). The impact of external social and internal personal forces on consumers' brand community engagement on Facebook. Journal of Product $\mathcal{E}$ Brand Management, 25(5), 409-423.

Sparks B., So, K.K.F. \& Bradley, G.L. (2016). Responding to negative online reviews: The effects of hotel responses on consumer inferences of trust and concern. Tourism Management, 53, 74-85. https://doi: 10.1016/j.tourman.2015.09.011

Shu-Chuan C., Che-Hui L. \& Yang C. (2019). Electronic word-of-mouth (eWOM) on WeChat: examining the influence of sense of belonging, need for self-enhancement, and consumer engagement on Chinese travellers' eWOM. International Journal of Advertising, 38(1), 26-49.

Tafesse, W. (2016). An experiential model of consumer engagement in social media. Journal of Product $\mathcal{E}$ Brand Management, 25 (5), 424-434.

Taylor, M., Haggerty, J., Gresty, D., Wren, C. \& Berry, T. (2016). Avoiding the misuse of social media by employee. Network Security, 5, 8-11.

Thoumrungroje, A. (2014). The influence of social media intensity and EWOM on conspicuous consumption. Procedia-Social and Behavioral Sciences, 148, 7-15. https://doi: 10.1016/j.sbspro.2014.07.009

TripAdvisor Insights (2015). Conclusiones clave del informe Using Guest Reviews to Pave the Path to Greater Engagement. Atmosphere Research Group.

Retrieved from: https://www.tripadvisor.es/TripAdvisorInsights/w842

Van Doorn, J., Lemon, K.N., Mittal, V., Nass, S., Pick, D., Pirner, P. \& Verhoef, P.C. (2010). Customer engagement behavior: Theoretical foundations and research directions. Journal of Service Research, 13(3), 253-266.

Walsh, G., Schaarschmidt, M. \& Von Kortzfleisch, H. (2016). Employees' company reputation-related social media competence: Scale development and validation. Journal of Interactive Marketing, 36, 46-59.

Wang, P. (2017). The Role of eWOM in customer engagement in travel service organizations: an affordance perspective. WHICEB, p. 4.

Wei, W., Miao, L. \& Huang, Z.J. (2013). Customer engagement behaviors and hotel responses. International Journal of Hospitality Management, 33, 316-330. https://doi: 10.1016/j.ijhm.2012.10.002

Williams, N. L., Inversini, A., Ferdinand, N. \& Buhalis, D. (2017). Destination eWOM: A macro and meso network approach? Annals of Tourism Research, 64, 87-101.

Williams, R., van der Wiele, T., van Iwaarden, J. \& Eldridge, S. (2010). The importance of user-generated content: the case of hotels. The TQM Journal, 22(2), 117-128. https://doi: 10.1108/17542731011024246

Wittink, D. R. \& Bayer, L. R. (2003). The measurement imperative. Marketing Research, 15(3), 19-19.

Wolny, J. \& Mueller, C. (2013). Analysis of fashion consumers' motives to engage in electronic word-ofmouth communication through social media platforms. Journal of Marketing Management, 29 (56), 562-583.

World Tourism Organization (2018). European Union Tourism Trends. UNWTO, Madrid.

Wu, S.H., Hsieh, Y.H., Chen, L.P., Yang, P.C. \& Fanghuizhu, L. (2018, August). Temporal Model of the Online Customer Review Helpfulness Prediction with Regression Methods. In IEEE/ACM International Conference on Advances in Social Networks Analysis and Mining, 27-38. Springer, Cham.

Xiang, Z., Du, Q., Ma, Y. \& Fan, W. (2017). A comparative analysis of major online review platforms: Implications for social media analytics in hospitality and tourism. Tourism Management, 58, 51-65. https://doi: 10.1016/j.tourman.2016.10.001

Xiang, Z. \& Gretzel, U. (2010). Role of social media in online travel information search, Tourism Management, 31(2), 179-188. 
Xu, Q. (2014). Should I trust him? The effects of reviewer profile characteristics on eWOM credibility. Computers in Human Behavior, 33, 136-144.

Zainal, N.T.A., Harun, A. \& Lily, J. (2017). Examining the mediating effect of attitude towards electronic words-of mouth (eWOM) on the relation between the trust in eWOM source and intention to follow eWOM among Malaysian travellers. Asia Pacific Management Review, 22, 35-44.

Zhang, M., Guo, L., Hu, M. \& Liu, W. (2017). Influence of customer engagement with company social networks on stickiness: Mediating effect of customer value creation", International Journal of Information Management, 37, 3, 229-240.

Zheng, X., Cheung, C.M., Lee, M.K. \& Liang, L. (2015), "Building brand loyalty through user engagement in online brand communities in social networking sites", Information Technology \& People, 28(1), 90-106.

Zhao, X., Wang, L., Guo, X. \& Law, R. (2015). The influence of online reviews to online hotel booking intentions. International Journal of Contemporary Hospitality Management, 27, (6), 1343-1364. https://doi:10.1108/IJCHM-12-2013-0542.

Received: 05/11/2019

Accepted: 11/o6/2020

Coordinating editor: Martina Gonzalez-Gallarza

Appendix 1. Measures for the variables

\begin{tabular}{|c|c|c|}
\hline Dimensions & Statements & Measures \\
\hline \multirow{4}{*}{ Hotel characteristics } & X1 Hotel category. & 3 stars; 4 stars; 5 stars; luxury hotel; others. \\
\hline & $\mathrm{X}_{2}$ Number of beds. & $\begin{array}{l}\text { Family (<100 beds); small (101-150 beds); medium } \\
(151-300 \text { beds); large (>300 beds). }\end{array}$ \\
\hline & $\mathrm{X}_{3}$ Number of employees. & $\begin{array}{l}\text { small (<10 employees); medium (11-50 employees); } \\
\text { large ( }>50 \text { employees). }\end{array}$ \\
\hline & $\mathrm{X}_{4}$ Ownership structure. & $\begin{array}{l}\text { Independent; member of an association of } \\
\text { independent hotels; member of a hotel's } \\
\text { chain; hotel's franchise. }\end{array}$ \\
\hline
\end{tabular}

$\mathrm{X}_{5}$ Consumers spoke of this company much more frequently than about any other similar company.

eWOM intensity $\quad$ X6 Consumers spoke of this company much (hoteliers' perception) more frequently than about companies of any other type.

$\mathrm{X}_{7}$ Consumers spoke of this company to many individuals.

X8 Choose the number that best describes the

intensity of your company's $10-$ item Likert scale/ each question
TripAdvisor usage in the sales $(1=$ strongly disagree; $10=$ strongly agree).
organisation.

X9 My organisation makes productive use of social media.

Xıo Our sales organisation is innovative and forward-thinking when it comes to

Competence adopting productivity-enhancing technology.

$\mathrm{X} 11$ The senior leadership of my organisation is knowledgeable about social media.

$\mathrm{X} 12$ The leadership of my organisation actively uses social media. 
X13 My organisation has communicated a social media usage policy to me.

Commitment

$\mathrm{X}_{14}$ My (total) organisation has a social media strategy.

$\mathrm{X}_{15}$ I have received sufficient training from my organisation on using social media.

eWOM intensity X16 Number of real reviews received.

Rank, from o to 387

Appendix 2

Hypotheses:

Result

H1a: According to hoteliers' perception of reviews received, review site use intensity is Not supported positively related to eWOM intensity.

Hıb: According to real number of reviews received, review site use intensity is positively Supported related to eWOM intensity.

H2a: According to hoteliers' perception of reviews received, organisational Not supported commitment is positively related to eWOM intensity.

H2b: According to real number of reviews received, organisational commitment is Not supported positively related to eWOM intensity.

Hza: According to hoteliers' perception of reviews received, organisational competence Not supported is positively related to eWOM intensity.

H3b: According to real number of reviews received, organisational competence is Not supported positively related to eWOM intensity. 